\title{
Dental and skeletal changes after intra-oral molar distalization using a "Distal Driver" appliance: a pilot study
}

\section{Zmiany zębowe i szkieletowe po zastosowaniu wewnątrzustnego aparatu do dystalizacji Distal Driver - badanie pilotażowe}

\section{Gabriela Urbaniak-Malinowska, Marta Gibas-Stanek, Stephen Williams, Wojciech Stós, Bartlomiej W. Loster}

Katedra Ortodoncii, Instytut Stomatologii, Wydział Lekarski, Uniwersytet Jagielloński Collegium Medicum, Kraków, Polska Chair of Orthodontics, Dental Institute, Faculty of Medicine, Jagiellonian University Medical College, Cracow, Poland Head: prof. B.W. Loster

\section{Abstract}

Introduction. Loss of space in the maxillary arch is a frequent consequence of early loss of deciduous molars indicating distalisation of the mesialised molar tooth. A number of methods using either extra-oral appliances or intra oral appliances of various types have been suggested. While extra-oral appliances exert a high but intermittent force many of the intraoral ones deliver a modest, though constant, force and demands no patient cooperation. Aim of study. To investigate the effect of an intra-oral fixed appliance (Distal Driver) based on a NiTi spring incorporating also a standardised anchorage unit on the position of the maxillary first molar as well as on the facial skeleton and the dentition in general. Material and methods. The experimental group comprised 6 child patients exhibiting a distal molar relationship (Unilateral or Bilateral) of at least 1/2 premolar unit. The mesialised molars were distalised by means of a "Distal Driver" exerting a force of $150 \mathrm{gm}$ for a period of 3-4 weeks. Anchorage was created by a fixed modified palatal bar cemented on the premolars supporting an acrylic palatal button ad modum Nance. The clinical situation was recorded before and after molar distalisation by means of study casts, cephalograms, panoramic radiographs as well as intra-oral photographs. The distalisation of the molars as well as the effect on anchorage teeth was quantitated on digital models derived from the plaster

\section{KEYWORDS:}

molar distalization, Class II malocclusion, intraoral distalizing appliance

\section{Streszczenie}

Wstęp. Niedobór miejsca w górnym luku zębowym będacy często konsekwencja przedwczesnej utraty zębów trzonowych mlecznych, wskazuje na konieczność dystalizacji przemieszczonych mezjalnie statych pierwszych zębów trzonowych. Dostępnych jest wiele metod uwzględniajacych użycie aparatów zewnątrzustnch bądź różnego typu aparatów wewnatrzustnych. Podczas gdy aparaty zewnatrzustne dostarczaja znacznej, lecz przerywanej sity, aparaty wewnatrzustne dzialaja wywolując średnie poziomy sit nawet przy braku wspótpracy ze strony pacjenta. Cel badania. Celem badania była ocena efektywności wewnatrzustnego statego aparatu (Distal Driver) opartego na otwartej sprężynce NiTi oraz standardowej jednostce kotwiącej $w$ dystalizacji pierwszych zębów trzonowych szczęki oraz jego wplywu na struktury szkieletowe $i$ zębowe. Material i metoda. Grupa badawcza składata się z 6 pacjentów $w$ wieku dziecięcym demonstrujących dystalna relację zębów trzonowych (jednostronnie lub obustronnie) w zakresie przynajmniej $1 / 2$ jednostki. Mezjalnie przemieszczone zęby trzonowe zdystalizowano aparatem „Distal Driver" wywierajac site 150g przez okres 3-4 tygodni. Zakotwienie uzyskano stosujac przerzut podniebienny cementowany do pierwszych zębów przedtrzonowych oraz wzmocniony guziczkiem podniebiennym na wzór aparatu Nance. Przed leczeniem oraz po

\section{HASŁA INDEKSOWE:}

dystalizacja trzonowców, wada klasy drugiej, wewnq̨trzustny aparat do dystalizacii 
casts. Evaluation of the observed distal and vertical changes in molar position was performed on the lateral cephalogram. Results. Cast analysis showed a clear distalising effect on the maxillary first molars ranging from $1.25 \mathrm{~mm}$ to $6.18 \mathrm{~mm}$ as well as mesial movement of the premolar anchorage teeth from 0.46 $\mathrm{mm}$ to $5.55 \mathrm{~mm}$. The cephalometric analysis revealed a first molar distalisation of $0.9 \mathrm{~mm}$ to $5.6 \mathrm{~mm}$ though again with a mesial movement of the first premolar varying from $0.5 \mathrm{~mm}$ to $3.7 \mathrm{~mm}$. A clear distal tipping of the first and second molars simultaneously with a mesial tipping of the first premolars was also recorded. Conclusion. The Distal Driver constitutes an efficient method of maxillary molar distalisation though is often accompanied by a distal rotation of these teeth and a mesial tipping of the anchorage premolars. Careful monitoring of anchorage loss is necessary if good results are to be achieved.

\section{Introduction}

Lack of space is a common orthodontic problem in the Polish population, often due to early loss of deciduous molars. Several methods of distalisation of maxillary first molars in order to create space in buccal segments have been described utilising both intra-oral and extra-oral appliances. Based on the principles of construction and/or anchorage method, distalisers can be catagorised in the following groups:

1) extra-oral appliances e.g. Headgear, ${ }^{1}$ Acrylic Cervical Occipital Appliance (ACCO) ${ }^{2}$

2) distalisers connected with fixed appliances e.g. Jasper Jumper ${ }^{3}$ repellent magnets, ${ }^{4}$

3) appliances involving palatal anchorage e.g. Pendulum ${ }^{\circledR},{ }^{5}$ intra-oral bodily molar distaliser (“Keles slider"), ${ }^{6}$ Distal Jet ${ }^{\circledR},{ }^{7}$ sectional jig assembly, "Jones Jig”' ${ }^{8}, 9$

4) appliances with skeletal anchorage e.g. TopJet $\AA, 10$ Skeletal "Frog" Appliance $\AA, 11$ Beneslider $\AA,{ }^{12}$ Bollard miniplates. ${ }^{13}$ zakończeniu dystalizacji wykonano dokumentacje w postaci modeli, zdjęć cefalometrycznych, zdjęć pantomograficznych oraz zdjęć fotograficznych wewnatrzustnych. Dystalizacja pierwszych zębów trzonowych oraz zmiany w położeniu zębów jednostki kotwiacej zostały ocenione na modelach cyfrowych otrzymanych na podstawie skanu modeli gipsowych. Pomiaru dystalizacji oraz zmian $w$ pionowym położeniu zębów trzonowych dokonano na zdjęciach cefalometrycznych. Wyniki. Analiza modeli wykazała dystalizację pierwszych zębów trzonowych szczęki w zakresie od 1,25 $\mathrm{mm}$ do 6,18 $\mathrm{mm}$ oraz mezjalizacje zębów przedtrzonowych właczonych do jednostki kotwiacej wielkości od 0,46 $\mathrm{mm}$ do 5,55mm. Zgodnie z analiza cefalometryczna uzyskano od $0,9 \mathrm{~mm}$ do 5,6mm dystalizacji pierwszych zębów trzonowych kosztem od $0.5 \mathrm{~mm}$ do $3.7 \mathrm{~mm}$ mezjalizacji zębów przedtrzonowych. Odnotowano także dystalne nachylenie pierwszych $i$ drugich zębów trzonowych z jednoczesnym mezjalnym nachyleniem pierwszych zębów przedtrzonowych. Wnioski. Aparat "Distal Driver" stanowi efektywna metodę dystalizacji pierwszych zębów trzonowych szczęki, jednak jego działaniu czesto towarzysza efekty uboczne $w$ postaci dystorotacji tych zębów oraz mezjalnego nachylenia zębów przedtrzonowych jednostki kotwiacej. W celu uzyskania pożadanych rezultatów wskazana jest uważna kontrola utraty zakotwienia.

\section{Wstęp}

Niedobór miejsca w strefach oporowych, który często występuje jako skutek przedwczesnej utraty mlecznych zębów trzonowych, stanowi powszechny problem w polskiej populacji. Opisano kilka metod dystalizacji pierwszych górnych zębów trzonowych w celu odtworzenia miejsca w odcinkach bocznych uwzględniając aparaty wewnątrz i zewnątrzustne. Na podstawie budowy oraz/lub typu zakotwienia dystalizatory mogą zostać zakwalifikowane do następujących kategorii: 1) aparaty zewnątrzustne, np. Headgear, ${ }^{1}$ Acrylic Cervical Occipital Appliance (ACCO), ${ }^{2}$

2) dystalizatory, które można łączyć z aparatem stałym, np. Jasper Jumper ${ }^{\circledR}{ }^{3}$ system magnetyczny, ${ }^{4}$

3) aparaty wykorzystujące zakotwienie podniebienne np. Pendulum ${ }^{\circledR},{ }^{5}$ wewnątrzustny dystalizator trzonowców ("Keles slider"), ${ }^{6}$ Distal Jet ${ }^{\circ},{ }^{7}$ sekcyjny aparat typu ,jig", 8 “Jones Jig"®, 9 
While several of the appliances named above have been in use for several years it is still not clear which appliance system is associated with the smallest number of undesirable adverse effects, and which produce the largest amount of molar distalisation.

\section{Aim of the present study}

The aim of present study was to evaluate the efficiency of the so-called Distal Driver - an intraoral buccal acting appliance for maxillary first molar distalisation, developed and successfully used in the Department of Orthodontics of Jagiellonian University in Cracow, Poland. Since numerous studies revealed that distalisation is often associated with various adverse effects such as anchorage loss (mesial movement of premolars and protrusion of incisors), molar extrusion and an increase in the vertical dimension, the aim of the present study was to examine the effect of distalisation with the "Distal Driver", including adverse side effects, and to compare the observed results with other distalisers, in particular with sectional jig assemblies. ${ }^{8}$

\section{Material and method}

This investigation was designed as a prospective study in which a standard procedure of "Distal Driver" usage was to be developed and assessed. The patient sample consisted of six patients, consecutively treated, with dental Class II or Class II subdivision, aged 9-14 years selected on the basis of the following criteria: a) no history of previous orthodontic treatment; b) presence of a clinically recognisable dental Class II relationship or Class II subdivision of at least a bilateral half premolar unit Class II molar relationship with moderate to large space deficiency in the maxillary arch; c) extraction therapy was not planned in connection with the expected orthodontic treatment. The exclusion criteria were: a) presence of a dental open bite b) lack of first premolars and c) patients for whom molar distalisation had been attempted previously by means of removable appliance therapy.
4) aparaty wykorzystujące zakotwienie szkieletowe, np. TopJet ${ }^{1},{ }^{10}$ aparat "Frog" ${ }^{\circ},{ }^{11}$ Beneslider ${ }^{\circledR},{ }^{12}$ minipłytki Bollarda. ${ }^{13}$

Pomimo, iż kilka z wymienionych aparatów stosowanych jest od wielu lat, wciąż nie jest do końca jasne, który z nich wywołuje najmniejsze efekty uboczne oraz który umożliwia największą dystalizację zębów trzonowych.

\section{Cel badania}

Celem badania była ocena efektywności aparatu „Distal Driver” - wewnątrzustnego dystalizatora pierwszych górnych zębów trzonowych z powodzeniem stosowanego w Poradni Ortodoncji Uniwersytetu Jagiellońskiego w Krakowie.

Ponieważ wiele prac potwierdziło, że dystalizacja jest często związana z różnymi efektami ubocznymi, jak utrata zakotwienia (mezjalizacja zębów przedtrzonowych czy wychylenie zębów siecznych), ekstruzja zębów trzonowych i wzrost wymiaru pionowego, celem poniższej pracy była ocena działania aparatu „Distal Driver”, ocena wywoływanych przez niego efektów ubocznych oraz porównanie z innymi dystalizatorami, ze szczególnym uwzględnieniem sekcyjnego aparatu typu, ,jig". 8

\section{Material i metoda}

Badanie było badaniem prospektywnym, w którym zostały przedstawione i ocenione standardowe procedury zastosowania aparatu „Distal Driver”. W badaniu brała udział grupa 6 pacjentów w wieku pomiędzy 9-14 lat, z zębową klasą drugą lub z podjednostką klasy drugiej. Grupa wyselekcjonowana była na podstawie następujących kryteriów: a) brak wcześniejszego leczenia ortodontycznego; b) obecność klinicznie rozpoznawalnej zębowej klasy drugiej lub klasy drugiej podjednostki, z minimum $1 / 2$ jednostki klasy drugiej, z umiarkowanym lub ciężkim stłoczeniem w łuku górnym; c) bez planowanych ekstrakcji $\mathrm{w}$ trakcie leczenia. Kryteria wykluczenia zawierały: a) obecność zgryzu otwartego; b) brak pierwszych zębów przedtrzonowych oraz c) pacjentów, u których była wcześniej zastosowana dystalizacja za pomocą aparatów wyjmowanych.

W każdym przypadku została zebrana standar- 
Table 1. Summary of subjects investigated

\begin{tabular}{ccccc} 
Patient & Sex & Age (at start) & $\begin{array}{c}\text { Treatment time } \\
\text { (months) }\end{array}$ & $\begin{array}{c}2^{\text {nd }} \text { molar present } \\
\text { (Yes/No) }\end{array}$ \\
\hline 1. L.K. & $\mathrm{F}$ & $13 \mathrm{y} 7 \mathrm{~m}$ & $7 \mathrm{~m}$ (bilateral) & $\mathrm{Y}$ \\
\hline 2. W.T. & $\mathrm{M}$ & $12 \mathrm{y} 9 \mathrm{~m}$ & $7 \mathrm{~m}$ & $\mathrm{~N}$ \\
\hline 3. T.W. & $\mathrm{M}$ & $13 \mathrm{y} 0 \mathrm{~m}$ & $6 \mathrm{~m}$ (bilateral) & $\mathrm{N}$ \\
\hline 4. O.N. & $\mathrm{F}$ & $14 \mathrm{y} 5 \mathrm{~m}$ & $5 \mathrm{~m}$ & $\mathrm{Y}$ \\
\hline 5. Z.J. & $\mathrm{F}$ & $11 \mathrm{y} 10 \mathrm{~m}$ & $3 \mathrm{~m}$ & $\mathrm{~N}$ \\
\hline 6. T.A. & $\mathrm{F}$ & $10 \mathrm{y} 11 \mathrm{~m}$ & $3 \mathrm{~m}$ & \\
\hline
\end{tabular}
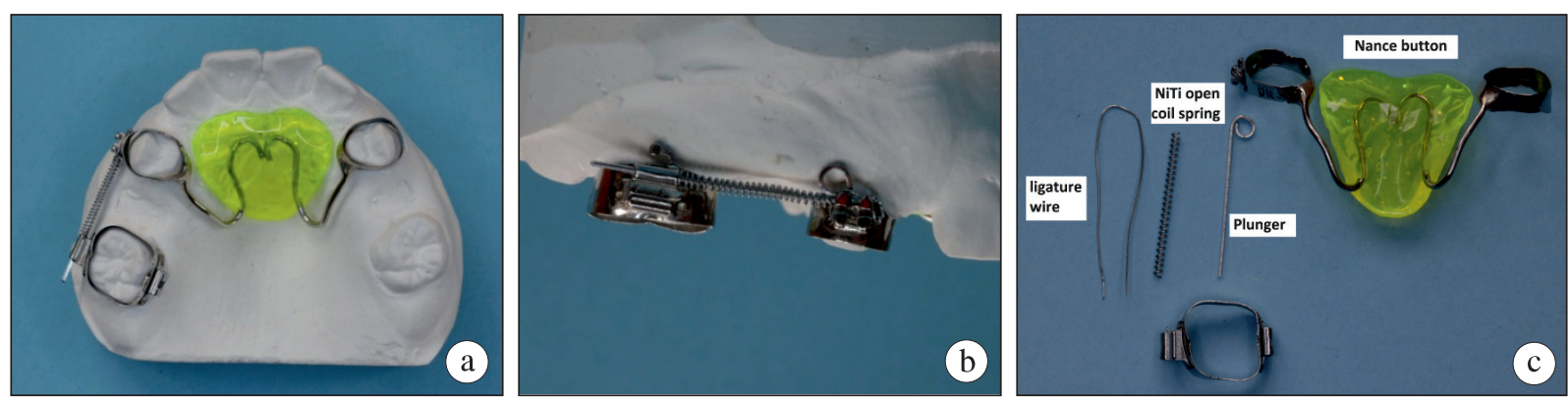

Fig. 1. The Distal Driver; a - Distal Driver in situ - occlusal view, b - Distal Driver in situ - lateral view, c - elements of the Distal Driver appliance. Distal Driver; a - Distal Driver in situ - widok na płaszczyzne okluzyina, b - Distal Driver in situ - widok boczny, c - elementy aparatu Distal Driver.

In each case standard orthodontic records were collected on the basis of a clinical examination supplemented with a radiographic examination (lateral cephalogram, orthopantomogram), study models, intra- and extra-oral photographs. The analysis of the dental and skeletal effects of the Distal Driver appliance was performed using lateral cephalometric radiographs, panoramic X-rays and virtual dental casts. Panoramic radiograph and lateral head films were taken prior to treatment (T1) and on the day the appliance was removed (T2) when a Class I molar occlusion was observed. Study models were made prior to treatment (M1) and on the day the appliance was removed (M2).

Details of the participants in the study as well as their age and treatment time and presence or absence of second molars can be seen in Table 1 .

The distal driver can be seen in Fig. 1 ( $a, b$, c). The anchorage control of the Distal Driver appliance is achieved by means of a modified "Nance button" appliance soldered to both first premolar bands ( $0.9 \mathrm{~mm}$ SS wire). On the buccal dowa dokumentacja diagnostyczna zawierająca badanie kliniczne, badania radiologiczne (zdjęcie cefalometryczne, ortopantomogram), modele diagnostyczne, fotografie wewnątrz- i zewnątrzustne. Analiza zębowych i szkieletowych efektów działania aparatu „Distal Driver” była przeprowadzona na podstawie analizy zdjęć cefalometrycznych, pantomograficznych oraz modeli wirtualnych. Zdjęcia cefalometryczne i pantomograficzne były wykonywana na początku leczenia (T1) oraz w dniu zdjęcia aparatu (T2), kiedy uzyskano relację na zębach trzonowych w klasie I. Modele gipsowe były wykonane na początku leczenia (M1) oraz po zakończonej dystalizacji w dniu zdjęcia aparatu (M2).

Charakterystyka pacjentów biorących udział w badaniu, dotycząca wieku, czasu leczenia oraz obecności lub braku drugich zębów trzonowych, zawarta jest w tabeli 1 .

Rycina 1 przedstawia budowę aparatu „Distal Driver”. Jednostkę kotwiącą aparatu stanowi zmodyfikowany „guzik Nance'a”, lutowany do 

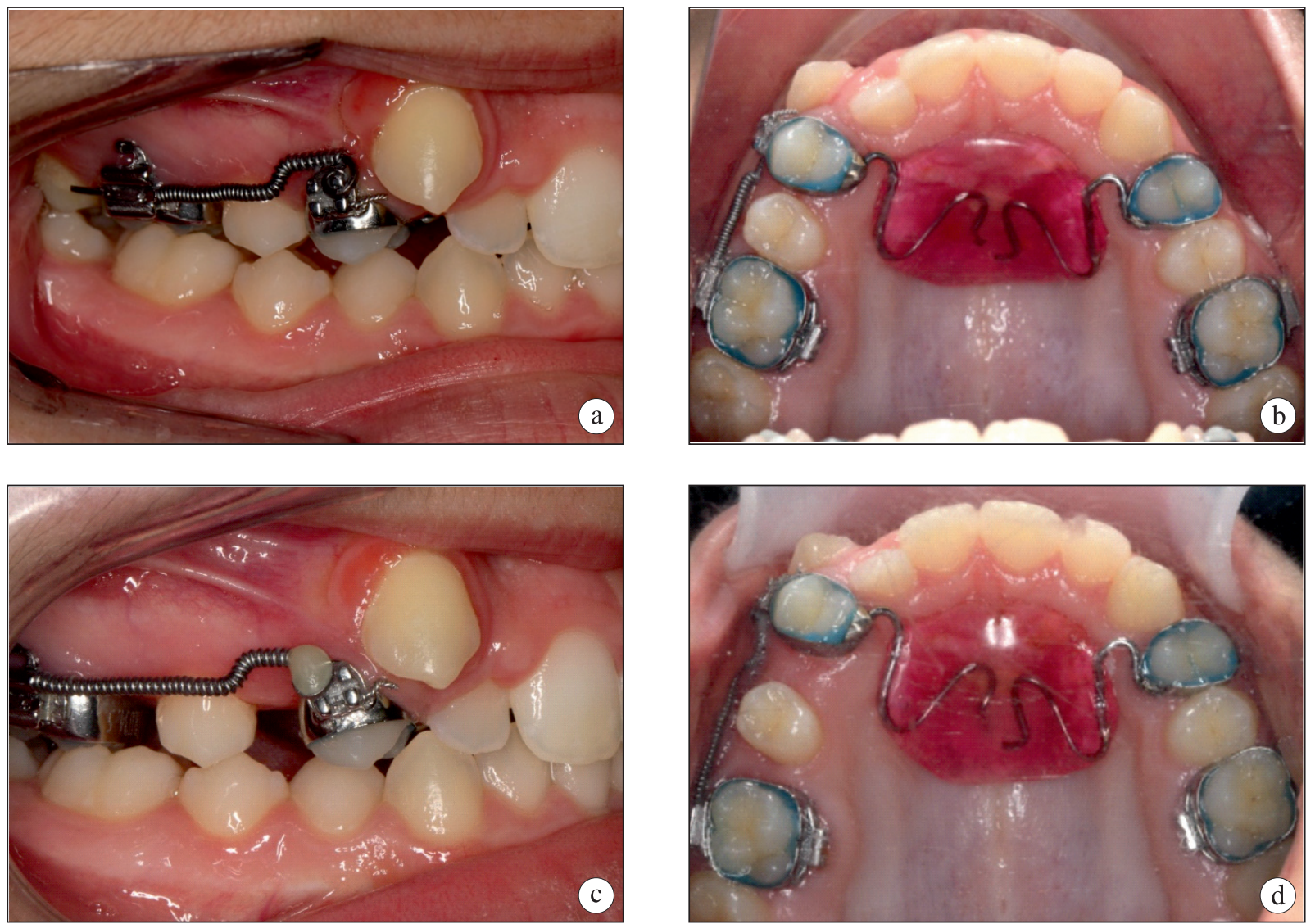

Fig. 2. Typical results of a Distal Driver appliance in connection with distalisation of $16 ; a, b$ - prior to activation, $c, d$ - after 5 months of activity. Typowy efekt dystalizacii aparatem Distal Driver na przykładzie dystalizacii zęba 16; a, b- przed aktywaciq, c, d- po 5 miesiacach aktywacii.

side, a bracket was welded to the premolar band and a buccal tube was welded to the maxillary first molar band (in single-sided distalisation) or to both maxillary first molar bands (in bilateral distalisation). The so-called "plunger" was formed in $0.017 " \mathrm{x} 0.025$ " stainless steel wire and was inserted in the auxiliary buccal tube on the first molar. The anterior end of the "plunger" was completed with a helix in order to enable it to tightly ligate to the bracket on the first premolar with.012" stainless steel ligature. The force system consisted of a 070 " x.040" mm NiTi open coil spring adjusted to exert a force of $150 \mathrm{gm}$ by means of compression on the plunger. The force was assessed with Correx Gram Force Gauge ${ }^{\circledR}$. The appliance and in particular the force system was controlled clinically every three weeks. In cases where bilateral distalisation was planned it was decided to distalise first the right side and subsequently the left side. pierścieni na pierwszych zębach przedtrzonowych górnych (drut stalowy $0,9 \mathrm{~mm}$ ). Na powierzchniach policzkowych pierścieni na pierwszych zębach przedtrzonowych zostały zgrzane zamki. Natomiast na powierzchniach policzkowych pierwszych zębów trzonowych szczęki zostały zastosowane rurki policzkowe, jednostronnie lub obustronnie w zależności od jedno- lub obustronnej dystalizacji. Prowadnica aparatu została wykonana $\mathrm{z}$ drutu stalowego 0,017 " x 0,025 " i wprowadzona do rurki dodatkowej na pierwszym zębie trzonowym. Przedni koniec prowadnicy jest zakończony helisą, którą należy mocno doligaturować do zamka na pierwszym zębie przedtrzonowym za pomocą metalowej ligatury,012". W celu uzyskania siły dystalizującej $150 \mathrm{mg}$ zastosowano sprężynę otwartą NiTi 017" x,040" (założona na prowadnicę aparatu). Siłę mierzono za pomocą urządzenia Correx Gram Force Gauge ${ }^{\circledR}$. Wizyty kontrolne odbywały się co 3 tygodnie. W obu- 


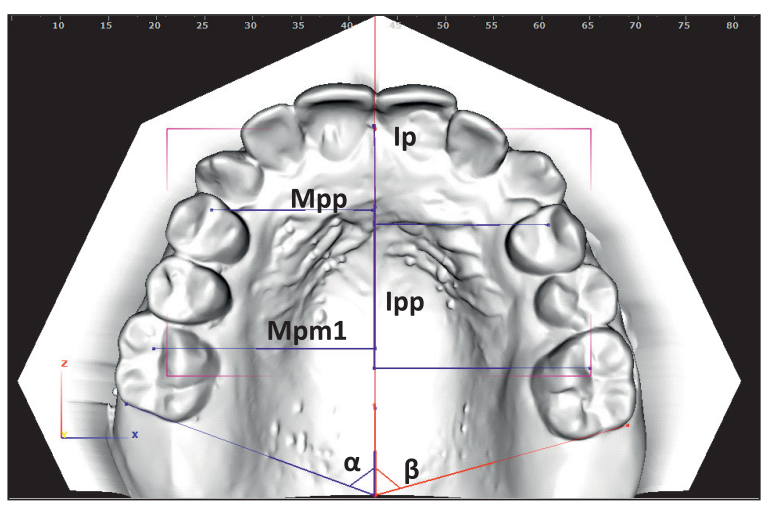

Fig. 3. Linear and angular parameters.

Pomiary liniowe i kqtowe.

\section{Clinical procedure}

The maxillary first premolars and maxillary first molars were banded. An alginate impression was taken with the bands in situ. The uncemented premolar bands were removed from the teeth and transferred onto the alginate impression. A stainless steel wire $0.9 \mathrm{~mm}$ was adapted to the palate and soldered onto the bands and subsequently an acrylic button was added in the centre of the anterior palatal region in order to enhance anchorage control.

The appliance was finished, polished and cemented in the mouth and activated according to the clinical protocol. The Distal Driver was activated every three weeks by compression of a new open coil spring placed on the plunger with force of $150 \mathrm{gm}$. The activated appliance as well as typical effects can be seen in situ in Figures 2 a-d.

\section{Measurement of parameters illustrating the effect of the "Distal Drive"}

(a) Parameters based on the digitalised model cast analysis. The landmarks, lines and angles were identified and recorded on the digital study models in DDP-Ortho software ${ }^{\circledR}$ and are demonstrated in Figure 3.

The following reference lines were constructed from the landmarks on the models prior to- (M1) and subsequent to- (M2) distalisation..$^{8,21}$

Ip - incisive papilla, Ipp (incisive papilla perpendicular) A line drawn posteriorly from the incisive papilla along the mid palatine raphe stronnej dystalizacji najpierw dystalizowano prawą, a następnie lewą stronę.

\section{Procedury kliniczne}

$\mathrm{Na}$ zęby pierwsze przedtrzonowe oraz pierwsze trzonowe szczęki założono pierścienie. Wykonano wycisk łuku górnego wraz z pierścieniami. Następnie przeniesiono niezacementowane pierścienie do wycisku. Drut stalowy 0,9 mm został dogięty do kształtu podniebienia, dolutowany do pierścieni na pierwszych zębach przedtrzonowych oraz zatopiony w guziku akrylowym pokrywającym przedni rejon podniebienia, stanowiący jednostkę zakotwienia. Gotowy aparat został wypolerowany, zacementowany w ustach pacjenta i zaktywowany według klinicznych procedur. „Distal Driver” był aktywowany co trzy tygodnie, poprzez kompresję nowej otwartej sprężyny NiTi na prowadnicy aparatu z siłą sprężyny $150 \mathrm{gm}$. Działanie zaktywowanego aparatu przedstawiają ryciny $2 \mathrm{a}-\mathrm{d}$.

\section{Pomiary parametrów opisujących działanie aparatu „Distal Driver”}

Parametry mierzono na zdygitalizowanych modelach diagnostycznych. Punkty, linie i kąty wyznaczone i zmierzone na modelach cyfrowych za pomocą programu DDP-Ortho ${ }^{\circledR}$ przedstawiono na rycinie 3 .

Na modelach przed (M1) oraz po dystalizacji (M2) wyznaczono następujące punkty oraz linie pomiarowe. $(8,12)$

Ip. Brodawka przysieczna, Ipp (linia prostopadła do brodawki przysiecznej). Jest to linia biegnąca prostopadle od tylnej granicy brodawki przysiecznej wzdłuż szwu podniebiennego.

Mpp. Linia biegnąca od bruzdy mezjalnej pierwszego stałego zęba przedtrzonowego szczęki prostopadle do lini Ipp (odpowiednio po prawej - R i lewej - L stronie).

Mpm1. Linia biegnąca od bruzdy mezjalnej pierwszego stałego zęba trzonowego szczęki prostopadle do lini Ipp (odpowiednio po prawej - R i lewej - L stronie).

Kąty $\boldsymbol{\alpha}$ i $\boldsymbol{\beta}$ - zawarte pomiędzy linią styczną do powierzchni dystalnej pierwszego zęba trzonowego szczęki a linią prostopadłą brodawki przy- 
Table 2. Results of the reproducibility study of the quantitative parameters used in the present study based on a statistical comparison of mean values determined by double determination evaluation

\begin{tabular}{|c|c|c|c|c|c|c|}
\hline Patient & Variable & Pre-treat $(M 1)$ & Post-treat (M2) & $\begin{array}{l}\text { Molar distal } \\
\quad(\mathrm{mm})\end{array}$ & $\begin{array}{l}\text { Premolar mesial } \\
\qquad(\mathrm{mm})\end{array}$ & $\begin{array}{c}\text { Molar rotation (ș) } \\
(\alpha \text {-right, } \beta \text {-left) }\end{array}$ \\
\hline \multirow{4}{*}{1} & MmplR & 27.76 & 30.29 & 2.53 & & \multirow{4}{*}{$\begin{array}{l}7.25(\alpha) \\
8.13(\beta)\end{array}$} \\
\hline & MmplL & 29.91 & 31.16 & 1.25 & & \\
\hline & PmpR & 9.21 & 8.45 & & 0.76 & \\
\hline & PmpL & 11.52 & 8.86 & & 2.66 & \\
\hline \multirow{4}{*}{2} & MmplR & 33.67 & 39.25 & 558 & & \multirow{4}{*}{$26.64(\alpha)$} \\
\hline & Mmpll & - & - & 5.58 & & \\
\hline & PmpR & 15.56 & 10.01 & & 555 & \\
\hline & PmpL & - & & & 5.55 & \\
\hline \multirow{4}{*}{3} & MmplR & 32.20 & 34.63 & 2.43 & & \multirow{4}{*}{$\begin{array}{l}9.78(\alpha) \\
1.99(\beta)\end{array}$} \\
\hline & MmplL & 32.38 & 35.38 & 3.00 & & \\
\hline & PmpR & 11.24 & 7.28 & & 3.96 & \\
\hline & PmpL & 11.92 & 11.46 & & 0.46 & \\
\hline \multirow{4}{*}{4} & MmplR & 27.92 & 32.45 & & & \multirow{4}{*}{$\begin{array}{c}14.12(\alpha) \\
-\end{array}$} \\
\hline & MmplL & - & & 4.53 & & \\
\hline & PmpR & 7.47 & 3.15 & - & 4.32 & \\
\hline & PmpL & 10.63 & 12.21 & & -1.56 (Distal) & \\
\hline \multirow{4}{*}{5} & MmplR & - & $\cdot$ & & & \multirow{4}{*}{$8.57(\beta)$} \\
\hline & Mmpll & 31.33 & 37.51 & & & \\
\hline & PmpR & 17.03 & 15.16 & 6.18 & 1.87 & \\
\hline & PmpL & 13.76 & 11.71 & & 2.05 & \\
\hline \multirow{4}{*}{6} & MmplR & - & - & $\cdot$ & \multirow{4}{*}{$\begin{array}{c}-0.46 \text { (Distal) } \\
1.08\end{array}$} & \multirow{4}{*}{$0.48(\beta)$} \\
\hline & Mmpll & 30.18 & 34.87 & 4.69 & & \\
\hline & PmpR & 14.28 & 14.74 & & & \\
\hline & PmpL & 12.07 & 10.99 & & & \\
\hline
\end{tabular}

Mpp. A line constructed from the mesial pit of the maxillary permanent first premolar at right angles to the Ipp ( $\mathrm{R}$ - right, $\mathrm{L}$ - left)

Mpm1. A line created from the mesial pit of the maxillary permanent first molar perpendicularly to the Ipp ( R - right, L - left)

Angles $\boldsymbol{\alpha}$ and $\boldsymbol{\beta}$ - constructed by a tangent drawn from the distal surface of the maxillary first molars projected onto the incisive papilla perpendicular Ipp, The angle thus formed was termed $\alpha$ on the right side and $\beta$ on the left.

All measurements were performed on the digital study models, by one investigator (GU-M), using a standardised procedure. The difference between the distance measured from Ip to Mpp (along Ipp) on both pre- and post-treatment models described the amount of first premolar mesialization in $\mathrm{mm}$ siecznej Ipp. Kąt po prawej stronie to kąt alfa, po lewej to kąt beta.

Wszystkie pomiary były wykonane na modelach wirtualnych przez jednego badacza (GU-M), według standardowych procedur. Różnica odległości pomiędzy Ip do Mpp, mierzona wzdłuż linii Ipp, na modelach przed i po dystalizacji, opisywała stopień mezjalizacji w milimetrach pierwszych przedtrzonowców (PmpR - strona prawa, PmpL - strona lewa). Stopień dystalizacji pierwszych trzonowców (w milimetrach) wyznaczano jako różnicę odległości od Ip do Mpm (wzdłuż Ipp), na modelach przed i po leczeniu (Mmp1R - strona prawa, Mmp1L strona lewa). Różnica pomiędzy kątami $\alpha$ a $\beta$, mierzona na modelach przed i po dystalizacji, pokazywała liczbę rotacji pierwszych trzonowców szczęki. Wyniki zamieszczono w tabeli 2. 
Table 3. Results demonstrating treatment-induced movement of molars and premolars in connection with molar distalisation

\begin{tabular}{lccccccc}
\multicolumn{1}{c}{ Variable } & Mean 1 & sdl & Mean 2 & sd2 & T & df & p \\
$\begin{array}{l}\text { Molar } \\
\text { distalisation }\end{array}$ & 3.774 & 1.723 & 3.891 & 1.637 & 1.665 & 7 & ns \\
\hline $\begin{array}{l}\text { Premolar } \\
\text { mesialization }\end{array}$ & 2.605 & 1.856 & 2.720 & 1.756 & 1.269 & 7 & ns \\
\hline $\begin{array}{l}\text { Molar } \\
\text { rotation }\end{array}$ & 9.62 & 8.112 & 8.36 & 4.816 & 0.637 & 7 & ns \\
\hline
\end{tabular}

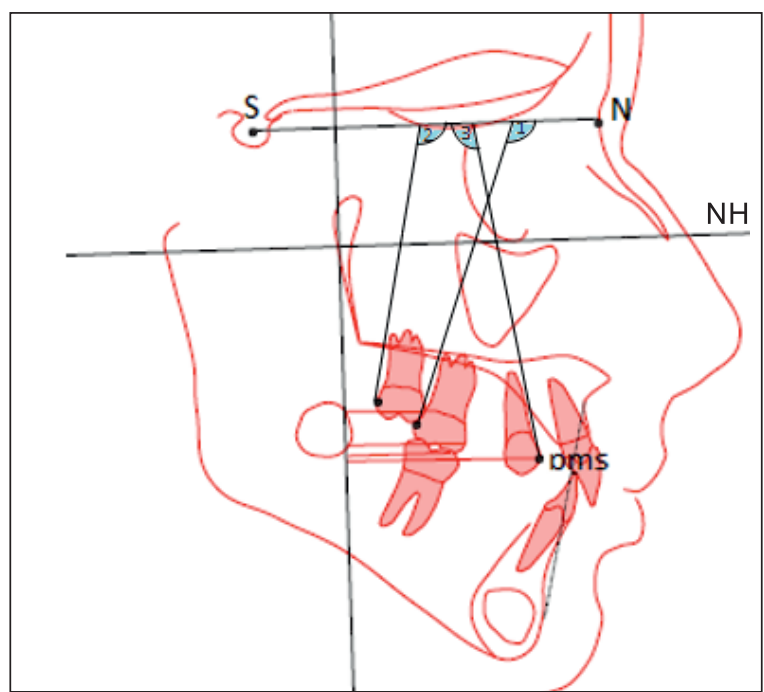

Fig. 4. Parameters created on a lateral cephalogram in order to quantitate molar and premolar movement in connection with Distal Driver treatment. Angles (I) and (2) describe the position of the first and second molars relative to the SN line and angle (3) relates to the position of the first premolar.

Pomiary wykonane na zdięciu cefalometrycznym w celu oceny zmiany potożenia zębów trzonowych i przedtrzonowych uzyskanych podzzas leczenia aparatem Distal Driver. Kąty (1) i (2) opisuia pozycie pierwszych i drugich zę̧bów trzonowych w stosunku do linii SN, kq̨ (3) odnosi się do połozienia pierwszego zęba przedtrzonowego.

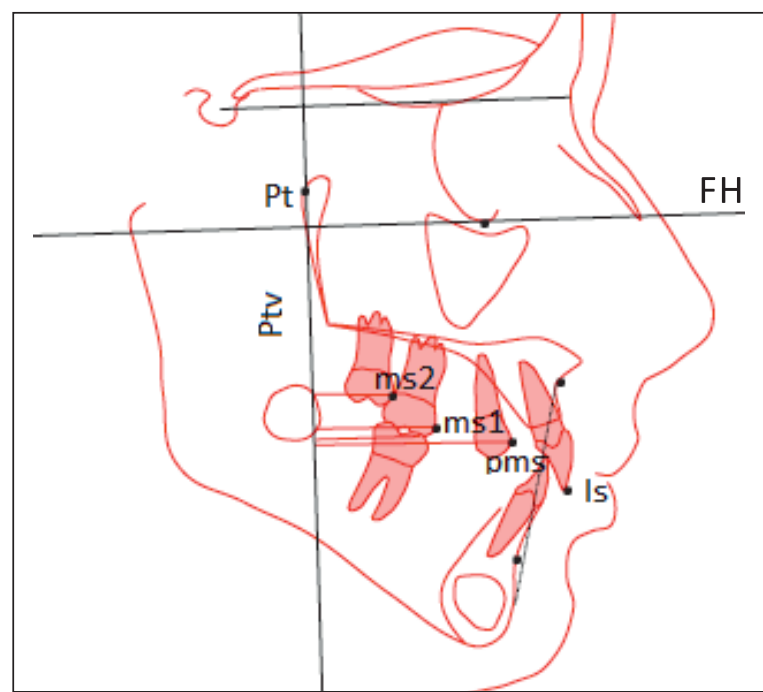

Fig. 5. A series of parameters intended to describe changes in sagittal and vertical molar and first premolar in connection with molar distalisation. The PTV vertical is used as the base line to which the sagittal and vertical positions of the teeth are measured; $m s \mathrm{l}$ - mesial surface of upper first molar, ms2 - mesial surface of upper second molar, pms mesial surface of upper first premolar.

Kilka parametrów opisuje zmiany w położeniu pierwszych zębów trzonowych w płaszczyźnie strzałkowej oraz pionowej w efekcie dystalizacij. Linia PTV została zastosowana jako linia bazowa, w stosunku do której wykonano pomiary poziome i pionowe; msl - mezialna powierzchnia pierwszego zęba trzonowego szzzęki, ms2 - mezialna powierzchnia drugiego zęba trzonowego szczęki, pms - mezialna powierzchnia pierwszego zęba przedtrzonowego szczęki.

Badanie powtarzalności parametrów ilościowych. Analiza powtarzalności powyższych pomiarów, była wykonana przez jednego obserwatora (GU-M). Pomiary liczono dwa razy. Wyniki powtarzalności znajdują się w tabeli 3 i wskazują na brak różnic istotnych statystycznie pomiędzy pierwszym a drugim pomiarem. Do analizy wykorzystano test t-Studenta.

W celu sprawdzenia efektów działania aparatu 
Table 4. Observed changes in the angulation of the first and second molars and first premolars in connection with molar distalisation (degrees to SN)

\begin{tabular}{cccc} 
Patient number & 7 (distal shift/tip) & 6 (distal shift/tip) & 4 (mesial shift/tip) \\
\hline 1 & $20.0^{\circ}$ & $3.4^{\circ}$ & $5.5^{\circ}$ \\
\hline 2 & $11.0^{\circ}$ & $12.7^{\circ}$ & $14.9^{\circ}$ \\
\hline 3 & $-3.7^{\circ}$ & $4.0^{\circ}$ & $5.9^{\circ}$ \\
\hline 4 & $2.2^{\circ}$ & $6.4^{\circ}$ & $5.5^{\circ}$ \\
\hline 5 & $8.4^{\circ}$ & $10.6^{\circ}$ & $9.0^{\circ}$ \\
\hline 6 & $3.9^{\circ}$ & $7.6^{\circ}$ & $6.5^{\circ}$ \\
\hline
\end{tabular}

Reproducibility of the study. The reproducibility of the above named parameters was investigated by a double determination of the parameters described by one observer (GU-M). The results can be seen in Table 3 where it can be seen that no statistically significant difference between the first and second evaluation, tested by means of a Student $t$ test could be established.

In order to investigate the effect of the Distal Driver appliance pre- and post distalisation cephalograms were traced by the same investigator. Dental angular parameters have been measured using a system described by Gulati et al. ${ }^{8}$ and Byloff et al. and can be seen in Figures 4, 5 and $6 .^{22}$

Referring to Figure 4 the angles 1,2 and 3 between the SN plane and a tangent drawn from the distal surface of the maxillary first and second molars and the mesial surface of the first premolar were measured. The differences in the pre- and post-treatment angles express the sum of tipping and distal movement that took place during the molar distalisation and are reported in Table 4.

Dental linear parameters were also measured. The linear parameters were intended to describe:

- amount of distalisation of the maxillary first and second molars,

- mesial movement of the maxillary first premolar,

- the amount of vertical extrusion of the maxillary first molar and first premolar.

The vertical axis was constructed as the "Ptv" line as described by Ricketts ${ }^{23}$ and based on
„Distal Driver” została wykonana analiza cefalometryczna przed i po dystalizacji, przez tego samego badacza. Zębowe kątowe pomiary zostały zmierzone według metody opisanej przez Gulati i wsp. ${ }^{8}$ oraz przez Bytloff i współpracowników. ${ }^{22}$ Ryciny 4, 5 i 6 przedstawiają metodę mierzenia.

Zgodnie z ryciną 4, zostały zmierzone kąty 1,2 i 3 zawarte pomiędzy płaszczyzną SN a styczną do dystalnej powierzchni pierwszych i drugich zębów trzonowych szczęki oraz styczną do mezjalnej powierzchni pierwszego zęba przedtrzonowego szczęki. Różnice pomiędzy zmierzonymi kątami przed i po dystalizacji określają stopień nachylenia i przesunięcia dystalnego podczas dystalizacji trzonowców. Wyniki podano w tabeli 4.

$\mathrm{W}$ badaniu zmierzono następujące zębowe $p a$ rametry liniowe:

- ilość dystalizacji pierwszych i drugich trzonowców,

- ilość mezjalizacji pierwszych zębów przedtrzonowych,

- zakres ekstruzji pierwszych zębów trzonowych i pierwszych zębów przedtrzonowych.

Wybrano oś pionową „Ptv” opisaną przez Rickettsa ${ }^{23}$, przechodzącą przez punkt „Pt” znajdujący się na dystalnym obrysie szczeliny skrzydłowo-podniebiennej i prostopadłą do poziomej płaszczyzny frankfurckiej. Parametry linowe poziome przedstawiono na rycinie 5 , parametry liniowe pionowe na rycinie 6 .

Zmierzono następujące parametry liniowe (Fig. 5): 
Table 5. Sagittal movement of the first and second molars and first premolars in connection with molar distalisation (mm to Ptv)

\begin{tabular}{cccc} 
Patient number & 7 (distal shift) & 6 (distal shift) & 4 (mesial shift) \\
\hline 1 & $3.1 \mathrm{~mm}$ & $1.8 \mathrm{~mm}$ & $1.3 \mathrm{~mm}$ \\
\hline 2 & $1.2 \mathrm{~mm}$ & $3.2 \mathrm{~mm}$ & $3.7 \mathrm{~mm}$ \\
\hline 3 & $0.2 \mathrm{~mm}$ & $2.2 \mathrm{~mm}$ & $3.2 \mathrm{~mm}$ \\
\hline 4 & $4.6 \mathrm{~mm}$ & $5.6 \mathrm{~mm}$ & $0.5 \mathrm{~mm}$ \\
\hline 5 & $6.6 \mathrm{~mm}$ & $5.3 \mathrm{~mm}$ & $0.6 \mathrm{~mm}$ \\
\hline 6 & $0.6 \mathrm{~mm}$ & $1.4 \mathrm{~mm}$ & $1.0 \mathrm{~mm}$ \\
\hline
\end{tabular}

Table 6. Changes in the vertical position of the first molars and first premolars related to vertical jaw relationship and inclination of the maxillary incisors

\begin{tabular}{ccccc} 
Patient & 6 (vertical) & 4 (vertical) & NL/ML & Is $/ \mathrm{NL}$ \\
\hline 1 & intr. $0.6 \mathrm{~mm}$ & extr. $1.2 \mathrm{~mm}$ & $+4^{\circ}$ & $0^{\circ}$ \\
\hline 2 & 0.0 & extr. $2.7 \mathrm{~mm}$ & $-2.5^{\circ}$ & $+7.0^{\circ}$ \\
\hline 3 & extr. $0.6 \mathrm{~mm}$ & extr. $1.6 \mathrm{~mm}$ & $0^{\circ}$ & $+1.1^{\circ}$ \\
\hline 4 & extr. $0.6 \mathrm{~mm}$ & extr $0.8 \mathrm{~mm}$ & $+2.2^{\circ}$ & $+3.4^{\circ}$ \\
\hline 5 & extr. $0.7 \mathrm{~mm}$ & extr. $1.9 \mathrm{~mm}$ & $-1^{\circ}$ & $0^{\circ}$ \\
\hline 6 & extr. $1.6 \mathrm{~mm}$ & extr. $2.3 \mathrm{~mm}$ & $+1.2^{\circ}$ & $+4.3^{\circ}$ \\
\hline
\end{tabular}

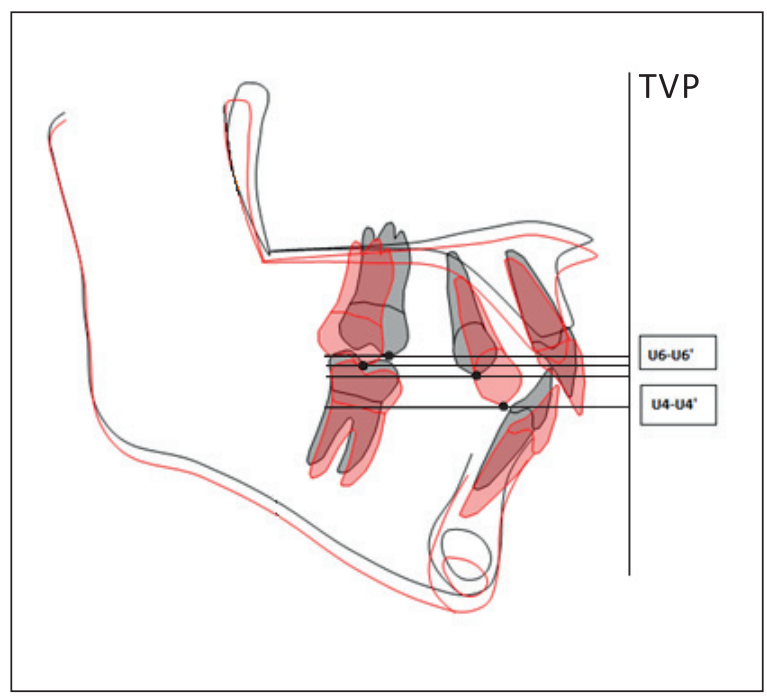

Fig. 6. Vertical changes in the first molar and first premolar position measured on superimposed images (general superimposition based on anterior cranial base); $\mathrm{U6}^{-} \mathrm{U6}^{\prime}$ - vertical distance between position of the mesial cusp of the upper first molar before and after distalisation (measured on True Vertical Plane), U4-U4' - vertical distance between position of the buccal cusp of the upper first premolar before and after distalisation (measured on True Vertical Plane).

Pionowe zmiany położenia pierwszych zębów trzonowych oraz pierwszych zębów przedtrzonowych zmierzono na nałozonych obrysach cefalometrycznych (generalna superimpozycja w oparciu na podstawie przedniego dołu czaszki); U6-U6' - pionowa odlegtość między pozycia guzka mezjalnego pierwszego zęba trzonowego przed oraz po dystalizacii (pomiar wykonano na prawdziwej linii pionowej), U4-U4' - pionowa odległośc między pozyciq guzka pierwszego zęba przedtrzonowego przed oraz po dystalizacii (pomiar wykonano na prawdziwej linii pionowej). 

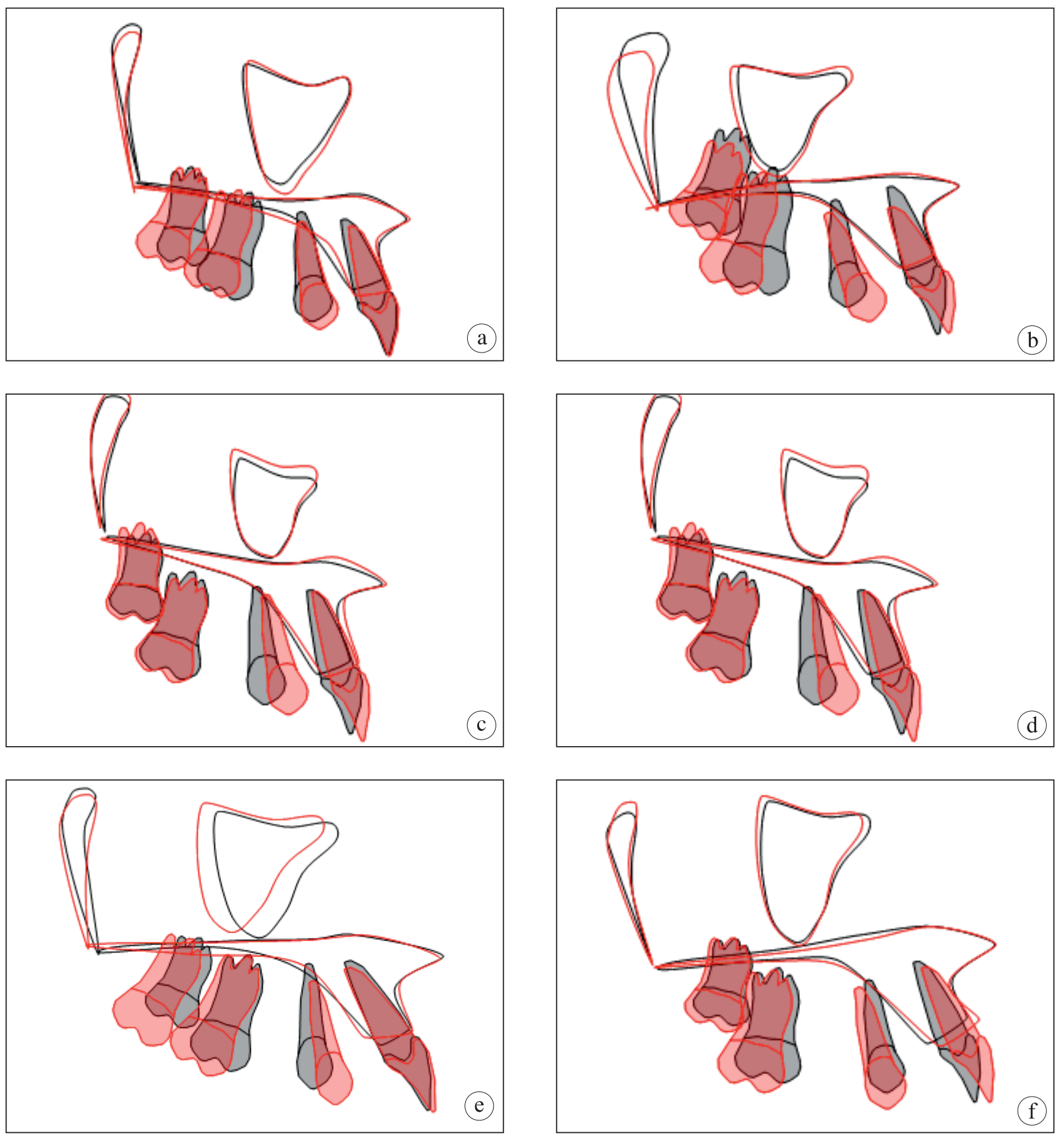

Fig. 7. Superimposed images of maxillary structures prior to and subsequent to molar distalization superimposed on the general position of the palatal plane. Sagittal and vertical changes can be observed.

Superimpozycja obrysów szczęki wykonanych przed oraz po dystalizacii, nałożonych zgodnie z płaszczyznq podniebiennq. Można zaobserwować zmiany w płaszczyźnie strzatkowej oraz pionowej.

a - patient L.K., b- patient W.T., c - patient T.W., d - patient O.N., e - patient Z.J., f - patient T.A.

the "Pt point" created at the distal outline of pterygo maxillary fissure and perpendicular to the F-H plane (Frankfort horizontal plane). The coordinates and parameters measured can be seen in Figure 5 (horizontal) and Figure 6 (vertical).
Różnicę odległości pomiędzy Ptv-ms1 opisującą stopień dystalizacji pierwszego zęba trzonowego szczęki (w mm).

Różnicę odległości pomiędzy Ptv-ms2 opisującą stopień dystalizacji drugiego zęba trzonowego szczęki w (mm). 
The following variables were constructed and measured (Fig. 5):

Change in the Ptv-ms1 distance corresponding to the amount of distalisation of maxillary first molar in $\mathrm{mm}$ )

Change in the Ptv-ms2 distance corresponding to the amount of distalisation of maxillary second molar in $\mathrm{mm}$ )

Change in the Ptv-pms distance representing the amount of mesial movement of maxillary first premolar in $\mathrm{mm}$ )

The results can be seen in Table 5 .

Extrusion of the first maxillary permanent molar and premolar can is based on the same coordinate system as Fig. 5 and can be seen in Fig. 6.

The vertical distance between U6 and U6' and U4 and U4' was measured on the Ptv plane on before and after radiographs were superimposed on the anterior cranial base structures. Results are presented in Table 6 .

The following skeletal changes were examined on pre- and post-distalisation cephalograms using standard cephalometric parameters, the results are also presented in Table 6 .

Upper incisor inclination: Ils/NL

Vertical jaw relationship: NL/ML

In order to obtain a general overview of changes taking place in the maxillary arch pre- and postdistalisation cephalograms describing just the maxillary structures based on the palatal plane were superimposed for each subject and can be seen in Figures 7 (A-F).

\section{Results}

The results of the linear analysis based on the quantitation of model casts are shown in Table 3 . The measurements on the virtual dental casts showed that there was a clear, though extremely variable, distal movement of the maxillary first molars (from $1.25 \mathrm{~mm}$ to $6.18 \mathrm{~mm}$ ) but also significant simultaneous mesial movement of the first premolars (from $0.46 \mathrm{~mm}$ to $5.55 \mathrm{~mm}$ ). Angles $\alpha$ and $\beta$ constructed by a tangent line drawn from the distal surface of the maxillary first molars and connected with incisive papilla perpendicularly reveal that the distalisation of maxillary molars was also accompanied by a distal rotation. In cases
Różnicę odległości pomiędzy Ptv-pms opisującą stopień mezjalizacji pierwszego zęba przedtrzonowego szczęki (w mm).

Wyniki pomiarów przedstawia tabela 5 .

Ekstruzję pierwszych zębów trzonowych w szczęce oraz pierwszych zębów przedtrzonowych zmierzono tak jak pokazują ryciny 5 i 6 .

Pionową odległość pomiędzy punktami U6 a U6' oraz U4 a U4' zmierzono na linii Ptv, nakładając zdjęcia cefalometryczne przed i po dystalizacji według struktur przedniego dołu czaszki. Rezultaty pokazano w tabeli 6.

W tabeli 6 zaprezentowano następujące zmiany szkieletowe, które zmierzono na zdjęciach cefalometrycznych, nakładając zdjęcia przed i po dystalizacji.

Inklinację górnego zęba siecznego: Ils/NL.

Pionową relację podstaw kostnych: NL/ML.

Rycina 7 (A-F) prezentuje generalne zmiany, jakie zaszły w szczęce podczas dystalizacji. Efekty dystalizacji zobrazowano poprzez superimpozycję struktur szczęki według płaszczyzny podniebienia.

\section{Wyniki}

Wyniki pomiarów liniowych wykonanych na modelach pokazuje tabela 3 . Pomiary wykonane na modelach wirtualnych pokazują wartości uzyskanej dystalizacji pierwszych zębów trzonowych szczęki (od 1,25 mm do 6,18 mm), oraz równoczesną mezjalizację pierwszych zębów przedtrzonowych (od 0,46 $\mathrm{mm}$ do $5,55 \mathrm{~mm}$ ). Kąty $\alpha$ i $\beta$ skonstruowane poprzez styczną do dystalnej powierzchni pierwszych zębów trzonowych szczęki oraz prostą prostopadłą do brodawki przysiecznej, potwierdzają dystalną rotację zębów towarzyszącą dystalizacji. W przypadku nr 4 i 6 z jednostronną dystalizacją, wystąpił dystalny ruch pierwszego zęba przedtrzonowego strony przeciwnej, co wskazuje na rotację całej jednostki kotwiącej.

Zmiany w strzałkowej pozycji zębów trzonowych i przedtrzonowych uzyskane podczas pomiarów cefalometrycznych zostały przedstawione w tabeli 5 i wykazały dystalizację pierwszych zębów trzonowych szczęki w zakresie od 1,4 $\mathrm{mm}$ do $5,6 \mathrm{~mm}$, jednocześnie zarejestrowano od $0,5 \mathrm{~mm}$ 
$\mathrm{n}^{\mathrm{o}} 4$ and 6 with unilateral distalisation a distal movement of the opposite premolar was noted, which indicates a rotation of the entire anchorage system.

The changes in the molar and premolar sagittal position measured on cephalometric X-ray and shown in Table 5 reveal that the maxillary first molar were distalised from $1.4 \mathrm{~mm}$ to $5.6 \mathrm{~mm}$, though the maxillary first premolar was recorded as moving forward from $0.5 \mathrm{~mm}$ to $3.7 \mathrm{~mm}$. This was confirmed by the angular measurements in Fig. 4 and Table 4. Both maxillary first $\left(3.4-12.7^{\circ}\right)$ and second $\left(-3.7-20.0^{\circ}\right)$ molars were also seen to tip distally, as can be seen in Table 4 .

Vertical changes in molar position are described in Table 6 where it can be seen that the $1^{\text {st }}$ molars extrude from 0.0 to $1.6 \mathrm{~mm}$ and $1^{\text {st }}$ premolar from 0.8 to $2.7 \mathrm{~mm}$. Increase in incisor proclination was observed from 0.0 to 7.0 degrees. Changes in the maxilla based on palatal plane superimposition can be seen for each subject in Figure 7. Presumably in some cases (A, C, F) correction of sagittal molar relation was achieved by a combination of distalisation and a favourable growth pattern of the mandible since the degree of molar distalisation can only be described as modest.

Considering the effect of first molar distalisation on the position of the second molar in one case (Fig. 7C) the second molar tipped $3.7^{\circ}$ mesially, whereas case A which had a mesially inclined second molar at the onset of the distalisation showed a distal tipping of $20^{\circ}$ enabling eruption in a correct inclination.

In the vertical plane the vertical jaw relationship generally increased to a maximum of 4.0 degrees though with case 2 revealing a slight decrease in vertical jaw relationship $\left(-2.5^{\circ}\right)$.

\section{Discussion}

A number of methods have been introduced for molar distalisation in situations where mesial movement of maxillary first molars has occurred usually in connection with early loss of deciduous molars as a result of caries. Amongst methods developed, intra-oral appliances are gaining popularity since they offer rapid correction by do 3,7 mm mezjalizacji pierwszych zębów przedtrzonowych.

Pomiary liniowe zostały potwierdzone przez pomiary kątowe przedstawione na rycinie 4 oraz w tabeli 4. Jak można odczytać w tabeli 4, zarówno pierwsze $\left(3,4-12,7^{\circ}\right)$, jak i drugie zęby trzonowe szczęki $\left(-3,7-20,0^{\circ}\right)$ przechyliły się dystalnie podczas leczenia.

Zmiany pionowe $\mathrm{w}$ pozycji zębów trzonowych przedstawiono w tabeli 6 , gdzie można odczytać, iż doszło do ekstruzji pierwszych zębów trzonowych w zakresie od 0,0 do $1,6 \mathrm{~mm}$ oraz od 0,8 do $2,7 \mathrm{~mm}$ w przypadku pierwszych zębów przedtrzonowych. Zaobserwowano wychylenie zębów siecznych wielkości 0,0-7,0 stopni. Zmiany, jakie zaszły w szczęce u poszczególnych pacjentów, zostały przedstawione na rycinie 7 jako superimpozycja wg płaszczyzny podniebiennej. Prawdopodobnie w niektórych przypadkach (A,C,F) korekta strzałkowej relacji zębów trzonowych nastąpiła zarówno dzięki dystalizacji, jak i korzystnemu wzrostowi żuchwy, ponieważ wielkość uzyskanej dystalizacji może być określona jako średnia.

Biorąc pod uwagę efekt dystalizacji pierwszych zębów trzonowych na położenie drugich zębów trzonowych, w jednym przypadku (Fig. 7C) drugi trzonowiec nachylił się $3,7^{\circ}$ mezjalnie, podczas gdy w przypadku A wyjściowo nachylony mezjalnie drugi ząb trzonowy przechylił się dystalnie o $20^{\circ}$, co umożliwiło jego prawidłowe wyrzynanie.

W wymiarze pionowym zaobserwowano tendencję do zwiększania kąta podstaw szczęk (maksymalnie o 4 stopnie), jednakże w przypadku pacjenta nr 2 doszło do niewielkiej jego redukcji $\left(-2.5^{\circ}\right)$.

\section{Dyskusja}

Istnieje wiele metod dystalizacji zębów trzonowych w przypadkach mezjalnego dryfu tych zębów na skutek wczesnej utraty zębów trzonowych mlecznych z powodu próchnicy. Wśród tych metod najbardziej popularne są aparaty wewnątrzustne, ponieważ umożliwiają szybką korektę poprzez przyłożenie niewielkiej, stałej siły, a wymogi współpracy z pacjentem są minimalne. Aparaty 
virtue of simple continuous force application often with minimal patient cooperation.

Extra-oral appliances require strict patient cooperation and forces exerted by such methods are intermittent and often result in a prolonged treatment time. ${ }^{1}$ Earlier reports suggest that when extra-oral traction is applied to the first molars, teeth tip distally and not by translation, which is often the movement of choice. ${ }^{1}$ In order to create bodily movement Cetlin $^{2}$ suggested combined mechanics with removable maxillary molar distalizing appliance with full-time use (to tip the crown distally) and part-time headgear (to control root position). Studies comparing cervical headgear and intra-oral distalisers with NiTi coil spring have suggested that the amount of distal movement of the maxillary first molars was significantly higher and more rapid where intraoral distalisers were used. ${ }^{14}$ The major problem concerning the intra-oral fixed methods for molar distalisation is, however, the loss of anchorage resulting in an increased overjet $(0.9 \mathrm{~mm})$ whereas the extra-oral traction created $0.9 \mathrm{~mm}$ decrease in overjet. ${ }^{14}$ Many non-compliance fixed appliances for maxillary molars distalisation have been described. . $^{8,15-18}$ The application of force in these appliances can occur from the buccal side, palatal side or both, and forces can involve friction (NiTi coil spring) or can be friction-free (pendulum appliance). ${ }^{19}$ Reports in the literature have stated that the anchorage loss may range between $25 \%$ and $80 \%$ with different techniques and appliances. ${ }^{9}$ Comparing buccal- and palatal-acting appliances, according to the literature palatal appliances act more closely to the centre of resistance of the teeth resulting in less tipping movements. ${ }^{16,17,19}$ Using palatal acting Distal Jet ${ }^{\circledR}$ a distalizing force on the maxillary molar resulted in $71 \%$ distalisation of the molar and $29 \%$ reciprocal anchorage loss measured at maxillary first premolar. ${ }^{15}$ It became clear that a Nance acrylic button is unable to resist reciprocal mesial force entirely. ${ }^{17}$ What is relevant, however, is that no significant vertical changes were observed. ${ }^{15}$ A report evaluating treatment with the Jones Jig ${ }^{\circledR}$ appliance (buccal acting appliance $)^{9,20}$ demonstrate that $38-44 \%$ of the intra arch space created was due to anchorage zewnątrzustne wymagają ścisłej współpracy pacjenta, a siły przyłożone z wykorzystaniem tych aparatów są siłami przerywanymi, czego efektem jest wydłużony czas leczenia. ${ }^{1}$ Wcześniejsze badania sugerują, że siły przyłożone do zębów trzonowych przy zastosowaniu wyciągu zewnątrzustnego nachylają te zęby dystalnie, a nie przesuwają osiowo, co jest ruchem pożądanym. ${ }^{1} \mathrm{~W}$ celu stworzenia ruchu translacyjnego Cetlin $^{2}$ zaleca połączenie aparatu ruchomego do dystalizacji zębów trzonowych szczęki, noszonego non stop (nachylenie koron dystalnie) wraz z headgerem do kontroli pozycji korzenia. Badania, które porównują działanie wyciągu szyjnego oraz działanie wewnątrzustnych aparatów do dystalizacji ze sprężyną NiTi sugerują, że ilość dystalnego ruchu pierwszych zębów trzonowych szczęki, była znacząco większa i w osiągana w szybszym tempie przy zastosowaniu aparatów wewnątrzustnych. ${ }^{14}$ Główny problem, który dotyczy aparatów wewnątrzustnych to utrata zakotwiczenia, czego objawem jest zwiększenie nagryzu poziomego (0.9 $\mathrm{mm}$ ), natomiast aparaty zewnątrzustne zmniejszają nagryz poziomy o $0,9 \mathrm{~mm} .{ }^{14}$

Opisano wiele stałych, nie wymagających współpracy aparatów do dystalizacji pierwszych zębów trzonowych. ${ }^{8,9,15-18}$. Przyłożenie sił w tych aparatach może być od strony policzkowej, podniebiennej lub z obu stron, a siły mogą powodować tarcie (sprężyna spiralna NiTi) albo działać beztarciowo (aparat pendulum). ${ }^{19} \mathrm{~W}$ literaturze podaje się różny stopień utraty zakotwiczenia, wynoszący pomiędzy $25 \%$ a $80 \%$ w różnych technikach i w różnych aparatach. ${ }^{9}$ Według doniesień literatury, porównując aparaty aktywowane od strony policzkowej i podniebiennej, aparaty podniebienne działają bliżej centrum oporu zębów, powodując mniej nachylenia. ${ }^{16,17,19}$ Aparat Distal Jet ${ }^{\circledR}$ aktywowany podniebiennie wywołuje siłę dystalizującą, co w rezultacie daje $71 \%$ dystalizacji pierwszych zębów trzonowych i 29\% utraty zakotwiczenia na pierwszych zębach przedtrzonowych. ${ }^{15}$ To oznacza, że akrylowy guzik podniebienny Nance'a nie daje całkowitego zakotwiczenia dla sił reakcji działających mezjalnie. ${ }^{17}$ Zaobserwowano brak znaczących zmian pionowych podczas dystalizacji. ${ }^{15}$ Badanie na temat le- 
loss and mesial movement of the second premolars. Maxillary second premolars extrusion of up to $1.88 \mathrm{~mm}$ and a $1.28 \mathrm{~mm}$ reduction of overbite was reported during molar correction. A tipping of the maxillary first molars of an average of $7.53^{\circ}$ has been reported. ${ }^{9}$

The purpose of the present study was to evaluate efficiency of "Distal Driver" intra-oral buccal acting appliance for maxillary first molar distalisation and compare it with sectional jig assembly, where palatal acrylic button was soldered both to the first and second premolar band. ${ }^{8}$ This study was undertaken to analyze the effect of Distal Driver on the dentition and skeleton relations. Our findings are that the distalisation of maxillary molars is effective but often accompanied by distal tipping and distal rotation of the molars. The amount of distalisation achieved with Distal Driver appears to be greater than that with sectional jig assemble. The measurement on the dental casts showed that the distal movement of maxillary first molars was $3.89 \mathrm{~mm}+/-1.63$ which compared with $2.95 \mathrm{~mm}$ $+/-0.89$ reported for the Gulati method. ${ }^{8}$

Mesial movement and mesial tipping of the maxillary first premolars was observed as an unfortunate side effect of molar distalisation due to the reciprocal force of the spring despite the presence of a modified Nance appliance. The amount of maxillary first premolar mesialization revealed in the present study was $2.72 \mathrm{~mm}+/-1.75$, which compares unfavourably with the report of Gulati (1.10 mm+/- 0.87).

In future treatment, reinforcement of the anchorage would be recommended possibly by strengthening the anchorage unit by increasing the dimensions of the palatal plate or alternatively by means of mini-implants. It is also possible that anchorage loss could be reduced by the application of lower forces, e.g. 75 grams.

Changes in the vertical plane are not consistent and may be related to individual growth patterns.

The present study indicates that the presence of second molars does not appear to have an effect on effectiveness of molar distalisation though the limited size of the experimental group reported in this study may make the results inconclusive.

The topic of the dental midline seems to be czenia aparatem Jones Jig® (aparat aktywowany od strony policzkowej $)^{9,20}$ pokazuje, że $38-44 \%$ uzyskanego miejsca w łuku, uzyskano poprzez utratę zakotwiczenia i ruch mezjalny drugich przedtrzonowców. Podczas dystalizacji trzonowców zanotowano ekstruzję drugich zębów przedtrzonowych rzędu $1,88 \mathrm{~mm}$ oraz zmniejszenie nagryzu pionowego o 1,28 $\mathrm{mm}$. Nachylenie pierwszych zębów trzonowych wynosiło średnio 7,53‥9

Celem tego badania była ocena efektywności działania wewnątrzustnego, aktywowanego od strony policzkowej aparatu „Distal Driver” do dystalizacji pierwszych zębów trzonowych szczęki i porównanie z sekcyjnym aparatem typu ,jig", w którym podniebienny guzik akrylowy był przylutowany do pierścieni na drugich zębach przedtrzonowych. ${ }^{8}$ Badanie przedstawia efekty zębowe oraz szkieletowe działania aparatu „Distal Driver”. Wnioski z badania potwierdzają, że dystalizacja pierwszych zębów trzonowych jest efektywna, ale zawsze towarzyszą jej dystalne nachylenie oraz dystalna rotacja zębów trzonowych. Stopień dystalizacji uzyskanej za pomocą aparatu „Distal Driver” jest większy niż w przypadku aparatu sekcyjnego typu ,jig”. Pomiary na modelach wskazują na większy stopień dystalizacji wynoszący $3,89 \mathrm{~mm}+/-1,63 \mathrm{w}$ porównaniu z badaniem przeprowadzonym przez Gulatiego 2,95 $\mathrm{mm}+/-0,89 .{ }^{8}$

Mezjalizacja oraz mezjalne nachylenie zębów przedtrzonowych wystąpiło jako uboczny efekt dystalizacji, z powodu sił reakcji pochodzących ze sprężyny, mimo obecności zakotwiczenia za pomocą zmodyfikowanego aparatu typu Nance'a. Zakres mezjalizacji zębów pierwszych przedtrzonowych wyniósł $2,72 \mathrm{~mm}+/-1.75 \mathrm{w}$ porównaniu do wyników Gulatiego 1,10 mm+/- 0,87. W kolejnych przypadkach, w celu wzmocnienia zakotwiczenia można zastosować płytę podniebienną o większym zasięgu albo wzmocnić zakotwiczenie za pomocą miniimplantu. Możliwe jest też zredukowanie utraty zakotwiczenia poprzez zmniejszenie przyłożonej siły wynoszącej około 75 gram. Zmiany w płaszczyźnie pionowej nie były powtarzalne i prawdopodobnie zależało to od indywidualnego wzorca wzrostu. Badanie wykazało, że obecność drugich zębów trzonowych nie miało wpływu na efektywność dystalizacji, ale zbyt mała 
relevant in connection with unilateral distalisation since midline deviation was observed in two of the cases studied after distalisation.

\section{Conclusion}

The conclusions of the present study can be summarised as follows.

The Distal Driver described in the present study appears to be a rational, simple and reasonably efficient method whereby maxillary first molars can be distalised. A good, well-controlled distal movement of the molars can be recorded though anchorage loss observed as mesial tipping of the maxillary premolars is frequently observed but in differing degrees. Secondary effects concerning the position of the second molars are variable. Longterm observation is needed to evaluate stability of the position of the molars during retraction of anterior teeth. grupa badawcza biorąca udział w badaniu, może dawać wyniki niejednoznaczne. Zaobserwowano również wpływ dystalizacji na przesunięcie linii środków, w dwóch przypadkach jednostronnej dystalizacji wystąpiła dewiacja linii środków.

\section{Wnioski}

Wnioski z przeprowadzonego badania można podsumować następująco. Aparat „Distal Driver” jest racjonalnym, prostym i efektywnym aparatem do dystalizacji pierwszych zębów trzonowych szczęki. Dobrze kontrolowanemu ruchowi dystalnemu zębów trzonowych szczęki, towarzyszyła utrata zakotwiczenia $\mathrm{w}$ postaci mezjalnego nachylenia zębów przedtrzonowych w różnym zakresie. Efekty wtórne dotyczące pozycji zębów drugich trzonowych są zmienne. Długoterminowa obserwacja jest konieczna, aby ocenić stabilność pozycji zębów trzonowych w trakcie retrakcji zębów przednich.

\section{References}

1. Graber TM: Extraoral force-fact and fallacies. Am J Orthod 1955; 4: 490-505.

2. Ferro F, Monsurrò A, Perillo L: Sagittal and vertical changes after treatment of class II division I malocclusion according to the Cetlin metod. Am J Orthod Dentofacial Orthop 2000; 118: 150-158.

3. Nalbantgil D, Arun T, Sayinsu K, Işık F: Skeletal, dental and soft-Tissue changes induced by the Jasper Jumper appliance in late adolescence. Angle Orthod 2005; 75: 426-436.

4. Bondemark L, Kurol J: Distalization of maxillary first and second molars simultaneously with repelling magnets. Eur J Orthod 1992; 14: 264-272.

5. Hilgers JJ: The pendulum appliance for Class II non-compliance therapy. J Clin Orthod 1992; 26: 700-713.

6. Keles A, Sayinsu K: A new approach in maxillary molar distalization: intraoral bodily molar distalizer. Am J Orthod Dentofacial Orthop 2000; 117: 39-48.

7. Carano A, Testa $M$ : The distal jet for upper molar distalization. J Clin Orthod 1996; 30: 374-380.

8. Gulati S, Kharbanda OP, Parkash H: Dental and skeletal changes after intraoral molar distalization with sectional jig assembly. Am J Orthod
Dentofacial Orthod 1998; 114: 319-326.

9. Brickman CD, Sinha PK, Nanda RS: Evaluation of the Jones jig appliance for distal molar movement. Am J Orthod Dentofacial Orthop 2000; 118: 526534.

10. Pseiner BC, Wunderlich, Freudenthaler JW: Upper molar distalization with skeletally anchored TopJet appliance. J Orofac Orthop 2014;75: 42-50.

11. Ludwig B, Glasl B, Kinzinger GSM, Walde KC, Lisson JA: The Skeletal Frog Appliance for maxillary molar distalization. J Clinic Orthod 2011; 45: 77-84.

12. Wilmes B, Drescher D: Application and effectiveness of the Beneslider: A device to move molars distally. World J Orthod 2010; 11: 331-340.

13. Cornelis MA, De Clerck HJ: Maxillary molar distalization with miniplates assessed on digital models: a prospective clinical trial. Am J Orthod Dentofacial Orthop 2007; 132: 373-377.

14. Bondemark L, Karlsson I: Extraoral vs intraoral appliance for distal movement of maxillary first molars: a randomized controlled trial. Angle Orthod 2005; 75: 699-706.

15. Bolla E, Muratore F, Carano A, Bowman J: 
Evaluation of maxillary molar distalization with the distal jet: a comparison with other contemporary methods. Angle Orthod 2002; 72: 481-494.

16. Kelese A: Maxillary unilateral molar distalization with sliding mechanics: a preliminary investigation. Eur J Orthod 200; 23: 507-515.

17. Bondemark $L$ : A comarative analysis of distal maxillary molar movement produced by a new lingual intra-arch Ni-Ti coil appliance and magnetic appliance. Eur J Orthod 2000; 22: 683-695.

18. Chaques-Asensi J, Kalra $V$ : Effect of pendulum appliance on the dentofacial complex. J Clin Orthod 2001; 35: 254-257.

19. Antonarakis GS, Kiliaridis S: Maxillary molar distalization with noncompliance intermaxillary appliances in class II malocclusion. Angle Orthod 2008; 78: 1133-1140.

20. Waheed-Ul-Hamid M, Arfan-Ul-Haq: Effects of Jones jig appliance in maxillary first molar distalization. Pakistan Oral Dent Jr 2006; 26: 203 210

21. Acar AG, Gursoy S, Dincer M: Molar distalization with a Pendulum appliance K-loop combination. Eur J Orthod 2010; 32: 459-465.

22. Byloff FK, Darendeliler A: Distal molar movement using the pendulum appliance. Part 1: Clinical and radiological evaluation. Angle Orthod 1997; 67: 249-260.

23. Ricketts RM: Perspectives in the Clinical Application of Cephalometrics. Angle Orthod 1981; 51: 115-150.

Address: 31-155 Kraków, ul. Montelupich 4

Tel.: +4812 4245402, Fax: +48124245494

e-mail: bwloster@gmail.com

Received: 9th May 2016

Accepted: $7^{\text {th }}$ Janury 2017 